\title{
A new species of Paramoera (Crustacea: Amphipoda: Pontogeneiidae) from an estuary habitat in Hokkaido, Japan
}

\section{$\operatorname{AUTHOR}(S):$}

Hagihara, Kumiko; Nakano, Takafumi; Tomikawa, Ko

\section{CITATION:}

Hagihara, Kumiko ... [et al]. A new species of Paramoera (Crustacea: Amphipoda: Pontogeneiidae) from an estuary habitat in Hokkaido, Japan. Journal of Natural History 2020, 54(19-20): 1279-1292

\section{ISSUE DATE:}

2020

URL:

http://hdl.handle.net/2433/255643

\section{RIGHT:}

This is an Accepted Manuscript of an article published by Taylor \& Francis in Journal of Natural History on 26 October 2021, available online: http://www.tandfonline.com/10.1080/00222933.2020.1785031.; The full-text file will be made open to the public on 26 October 2021 in accordance with publisher's 'Terms and Conditions for Self-Archiving'.; $こ の$ 論 文は出版社版でありません。引用の際には出版社版をご確認ざ利用ください。; This is not the published version.

Please cite only the published version. 
1 A new species of Paramoera (Crustacea: Amphipoda: Pontogeneiidae) from an estuary

2 habitat in Hokkaido, Japan

3

4 Kumiko Hagihara $^{\mathrm{a}}$, Takafumi Nakano ${ }^{\mathrm{a}, \mathrm{b}}$ and Ko Tomikawa ${ }^{\mathrm{a}}$

$6 \quad$ aapartment of Science Education, Graduate School of Education, Hiroshima University,

7 Higashihiroshima 739-8524, Japan

8 E-mail: tomikawa@hiroshima-u.ac.jp

$9 \quad$ bepartment of Zoology, Graduate School of Science, Kyoto University, Kyoto 606-8502

10 Japan

E-mail: nakano@zoo.zool.kyoto-u.ac.jp

CONTACT Ko Tomikawa tomikawa@hiroshima-u.ac.jp

\section{Acknowledgements}

We thank Mr. Masaki Kyono (Sapporo Technical College) for providing valuable specimens of the new species. The authors are also grateful to two anonymous reviewers for their valuable comments on this manuscript. 
Disclosure statement

No potential conflict of interest was reported by the authors

\section{Funding}

26

This study was financially supported by JSPS KAKENHI Grant Numbers JP17K15174,

JP15J00720, and JP17H00820.

29

\section{Geolocation information}

KUZ Z2041-Z2043 (point): $43.332857^{\circ} \mathrm{N}, 140.410445^{\circ} \mathrm{E}$

\section{ORCID}

Takafumi Nakano https//orcid.org/0000-0001-6107-2188

Ko Tomikawa http://orcid.org/0000-0003-1521-9016 


\section{ABSTRACT}

40

A new species of the pontogeneiid amphipod, Paramoera shakotanensis, from the mouth of Horonaifu River, Hokkaido, Japan, is described. Paramoera shakotanensis sp. nov. can clearly be distinguished from its congeners by a combination of the following features: large eyes, deep antennal sinus without sharp incision, epimeral plate 3 with smooth posterior margin, small number of setae on inner plate of the maxilla 1 (up to three) and on inner plate with oblique inner row (up to two), pereopod 7 with coxal gill, and distally tapering telson with almost straight lateral margins bearing submarginal setae.

http://zoobank.org/urn:lsid:zoobank.org:pub:72E1F36D-87E5-406A-B92D-6DE686150F99

\section{KEYWORDS}

Gammaridea; Pacific Ocean; estuary; brackish water

\section{Introduction}

Paramoera Miers, 1875 is the most species-rich genus within the family Pontogeneiidae and contains more than 50 species, which inhabit mainly cold marine habitats but are occasionally found in brackish or freshwater (Staude 1995; Sidorov 2010; Jung et al. 2016). The type 
58

species, Paramoera australis Miers, 1875, was described from Kerguelen Island in the southern Indian Ocean and is an epigean amphipod. However, several other species in the genus, described from the northern Pacific Rim region, are hypogean crustaceans (Staude 1995; Sidorov 2010; Nakano and Tomikawa 2018).

Before this study, none of hypogean Paramoera amphipods had been recorded from coastal areas in the northwestern Pacific. Three Paramoera species, i.e. P. erimoensis Kuribayashi and Kyono, 1995, P. hanamurai Hirayama, 1990, and P. koysama Kuribayashi and Kyono, 1995, were described from epigean waters of Hokkaido, Japan, and all of them were classified within Paramoera sensu stricto (Hirayama 1990; Kuribayashi and Kyono 1995). Paramoera relicta Uéno, 1971 is a subterranean species inhabiting an underground water habitats of an insular lava tube in Fukuejima island, Goto Islands, Japan (Uéno 1971; Nakano and Tomikawa 2018). In 2012, several specimens of an unidentified Paramoera species were collected from a river mouth in Hokkaido, Japan by Masaki Kyono of Sapporo Technical College, and given to the last author. After careful examination, detailed below, we concluded that these specimens belonged to a distinctive species, and thus describe and illustrate them herein as a new species belonging to the genus Paramoera.

\section{Material and methods}

\section{Sample collection}


77

78

79

80

81

82

83

84

85

86

87

88

89

90

91

92

Paramoera amphipods were collected from under stones at a river mouth of Horonaifu River,

Shakotan Peninsula, Hokkaido, Japan using a fine-mesh hand-net. Specimens were fixed and preserved in 99\% ethanol.

\section{Morphological examination}

All appendages of the specimens were dissected in $80 \%$ ethanol and mounted in gum-chloral medium on glass slides using a stereomicroscope (Olympus SZX7; Olympus, Tokyo, Japan).

The specimens were examined using a light microscope (Nikon Eclipse Ni; Nikon, Tokyo, Japan), and illustrated with the aid of a camera lucida. Body length (BL: to the nearest 0.1 $\mathrm{mm}$ ) was measured from the rostrum tip to the telson base, along the dorsal curvature. The specimens examined in this study have been deposited in the Zoological Collection of Kyoto University (KUZ).

\section{Taxonomy}

Family Pontogeneiidae Stebbing, 1906

Genus Paramoera Miers, 1875

Paramoera shakotanensis sp. nov.

(New Japanese name: Shakotan-migiwa-yokoebi) 
Paramoera sp.: Tomikawa et al., 2014: fig 2; Tomikawa et al., 2017: fig. 2.

Paramoera sp. 1: Nakano and Tomikawa, 2018: fig. 4, table 1.

\section{Type material}

102

Holotype. Female (BL 4.6 mm), KUZ Z2041, collected from Horonaifu River

(43.332857º, $\left.140.410445^{\circ} \mathrm{E}\right)$, Shakotan, Hokkaido, Japan, by Masaki Kyono, on 13 May

2012.

Paratypes. In total 3 females: female (BL 5.3 mm), KUZ Z1939, female (BL 5.6 mm), KUZ

\section{Diagnosis}

Head with large eyes; peduncular article 2 gland cone of antenna 2 with 2 apical setae; lacinia

111 mobilis of left mandible 5-dentate; mandibular palp article 3 without B-setae; inner plate of maxilla 1 with 3 plumose setae; gnathopod 2, carpus longer than propodus; coxa of pereopod of pleopods 1-3 with facial setae; uropod 2 inner ramus longer than outer ramus; telson 
115 longer than wide.

\section{Description}

Female [holotype, KUZ Z2041]. Body smooth. Rostrum (Figure 2(a)) short, weakly

produced; lateral cephalic lobe mammilliform; inferior antennal sinus quadrate, corner of

sinus rounded, not incised; eyes sub-oval, large, 0.4 times as high as head. Epimeral plates 1-

3 (Figure 2(b-d)): lateral surface with many tiny setae; posterior margins without crenulation,

with seta; posterodistal corners slightly pointed, with seta; plate 1 with long seta on ventral

submargin; plate 3 with 1 or 2 short setae and short bifid seta on ventral submargin.

Antenna 1 (Figure 2(e), 2(f)): length 0.5 times as long as body length; peduncular articles

1 with short setae on anterior margin, 2 single and 1 cluster of setae on posterior margin,

posterodistal corner with single seta and pair of setae; peduncular article 2 with short seta on anterior margin, 2 clusters of setae on posterior margin, anterodistal and posterodistal corners

with cluster of setae; peduncular article 3 with cluster of setae on posterior margin, 
134

135

136

137

138

139

140

141

142

143

144

145

146

147

148

149

150

151

152

1.9 : 1.9; gland cone length 0.8 times that of peduncular article 3, not prolonged, with 2 apical setae; peduncular article 3 with pair of setae on anterior margin, 3 setae on medial face of semi-circular elevation, single seta on lateral face, 3 setae on posterodistal corner; peduncular article 4 with 3 pairs or clusters of setae on anterior margin, 3 pairs of setae on medial surface, and a few short setae on posterior margin; peduncular article 5 with single seta and 2 pairs of setae on anterior margin, short single seta on posterior margin, 2 pairs of setae on medial surface, cluster of setae on anterodistal and posterodistal corners; flagellum with $10+$ articles (some distal articles broken); calceoli absent.

Upper lip (Figure 2(i)) ventral margin convex, rounded, with minute setae. Left and right mandibular incisors (Figure 2(j), 2(k)) 6-dentate, with left lacinia mobilis 5-dentate and right tridentate; left and right accessory setal rows with 6 and 5 blade setae, respectively; molar process triturative with plumose seta; palp 3-articulate, length ratio of left and right palp articles 1-3 1.0:2.7:2.4 and 1.0:2.5:2.2, article 1 bare, article 2 with 10 setae, article 3 with pair of A-, 2 C-, 5 D- and 7-E setae, lateral surface with many fine setae. Lower lip (Figure 2(l)) outer lobes broad, setulose, mandibular lobes narrow; inner lobes indistinct. Maxilla 1 (Figure 2(m), 2(n)) inner plate narrow with 3 plumose setae; outer plate rectangular with 10 serrate robust setae; palp 2-articulate; article 1 bare; article 2 with 6 robust and 1 slender setae on apical and subapical margins, respectively, outer margin without setae. Maxilla 2 (Figure 2(o)) inner plate with oblique inner row of 2 plumose setae; outer plate with about 19-20 
153

154

155

156

157

158

159

160

161

162

163

164

165

166

167

168

slender setae on subapically. Maxilliped (Figure 3(a)) inner plate not exceeding palp article 1,

with 3 robust setae subapically, medial face with oblique row of plumose setae; outer plate

exceeding palp article 1, with 2 thick plumose setae and robust setae apically; palp 4-

articulate, article 2 oblong, with a row of setae, article 3 unlobate, article 4 shorter than article

3, nail present and not spinose along the inferior margin but with 3 sub-apical setae.

Gnathopod 1 (Figure 3(d), 3(e)) shorter than gnathopod 2; coxa subrectangular, left and

right coxae with 6 and 4 short setae on ventral margins, respectively; basis length about 3

times longer than wide, with long setae on anterior and posterior margins, and inner surface;

ischium with setae on posterodistal corner; merus with long ventral setae; carpus 0.8 times as

long as propodus, with finely serrate setae on posterodistal corner; propodus subrectangular,

length 1.9 times longer than wide; left propodus with single seta, pair and cluster of setae on

anterior margin, single seta and 2 clusters of setae on posterior margin, right propodus single

seta and pair and cluster of setae on anterior margin, 2 clusters of setae on posterior margin,

palm (Figure 3(e)) oblique, about 0.6 times as long as posterior margin, smoothly connected

with posterior margin by 2 medial and 2 lateral robust setae; dactylus with seta on anterior

margin and 2 short setae subapically, nail indistinct. Gnathopod 2 (Figure 3(f), 3(g)) coxa with

6 setae on ventral margin; basis sub-linear, length about 3 times longer than wide, with

anterior and posterior marginal setae; ischium with 3 setae on posterodistal corner; merus with

long setae distally; carpus 1.2 times as long as propodus; propodus subrectangular, length 2.3 
172 times longer than wide, with 2 pairs and cluster of setae on posterior margin, palm (Figure

173 3(g)) oblique, about 0.5 times as long as posterior margin, smoothly connected with posterior

174 margin by 3 medial and 1 lateral robust setae in left gnathopod 2, by 4 medial and 1 lateral

175 robust setae in right one; dactyl similar to that of Gnathopod 1.

Pereopod 3 (Figure 4(a)) coxa ovate, with 6 short setae on ventral margin and robust seta on posterodistal corner; length ratio of from basis to propodus 1.0:0.2:0.6:0.5:0.6; basis subliner, with long setae on anterior and posterior margins; ischium with 2 setae on posterodistal corner; merus with 2 setae on anterior margin, single seta and cluster of setae on posterior margin; carpus with seta on anterior and posterior margins; propodus with 2 setae on anterior margin, 2 robust and 1 slender setae on posterior margin; dactyls 0.4 times as long as propodus, bearing seta on anterior margin and 2 minute setae subapically. Pereopod 4 (Figure 4(b)) coxa with shallow posterior concavity, right ventral margins of left and right coxae with 10 and 8 short setae, respectively; length ratio from basis to propodus 1.0:0.3:0.6:0.6:0.6; anterior and posterior margins of basis with long setae; ischium with 1 or 2 setae on posterodistal corner; merus with 1 or 2 setae on anterior margin, 2 setae on posterior margin;

187 anterior and posterior margins of carpus with 1 and 2 setae, respectively; propodus with 2 setae on anterior margin, single and pair robust setae on posterior margin; dactyl 0.3 times as long as propodus, bearing seta on anterior margin and 2 minute setae subapically. Pereopod 5 (Figure 4(c)) coxa bilobed, anterior lobe with small seta, posterior lobe with 2 robust and 1 
191

192

194

195

196

197

198

199

200

201

202

203

204

205

206

207

small setae; length ratio from basis to dactylus 1.0:0.3:0.7:0.7:0.8:0.3; basis ovate,

posteroventrally lobate; ischium with pair of setae on anterodistal corner; merus with single and pair of setae on anterior margin, robust seta on posterior margin; carpus with single and pair of robust setae on anterior margin, posterior margin with seta; propodus with 2 pairs of robust setae on anterior margin, single and pair of setae on posterior margin; dactylus with seta on posterior margin and 2 small subapical setae. Pereopod 6 (Figure 4(d)) coxa bilobate, posterior lobe with 1 robust and 1 slender setae; length ratio from basis to dactylus 1.0:0.3:0.8:0.7:0.8:0.3; basis ovate, posteroventrally lobate; ischium with 2 setae on anterodistal corner; merus with single and pair of setae on anterior margin, robust seta on posterior margin; carpus with single and pair of robust setae on anterior margin, posterior margin with 2 robust setae; propodus with 2 single and 1 pair of robust setae on anterior margin, single and pair of robust setae on posterior margin; dactylus with seta on posterior margin and 2 small subapical setae. Pereopod 7 (Figure 4(e)) coxa semicircular with 3 setae on posteroventral margin; length ratio from basis to dactylus 1.0:0.2:0.6:0.6:0.7:0.2; basis ovate, posteroventrally lobate; ischium with 2 setae on anterodistal corner; anterior and posterior margins of merus and carpus with 2 robust setae; propodus with single and 2 pairs of robust setae on anterior margin, 2 robust and 1 small setae on posterior margin; dactylus with seta on posterior margin and small subapical seta. 
210 and hump absent. Brood plates (Figure 3(h), 3(i)) on gnathopod 2, pereopods 3 and 4 large,

211 brood plate on pereopod 5 small, narrow, strap-like.

Pleopods 1-3 (Figure 5(a-c)) peduncles with paired retinacula on inner distal margin, and with facial setae; pleopods 1-3 inner ramui 7-, 8- and 7-articulate, respectively, with bifid plumose setae (clothes-pin setae) on inner basal margins, terminal setae on rami length 0.7-

2150.9 times that of rami; outer rami 10-, 10- and 9-articulate, respectively.

4-5 robust setae along medial and lateral ridges, respectively, basofacial seta absent; inner

219 length 0.9 times that of inner ramus, with outer marginal robust seta. Uropod 2 (Figure 5(e))

221 inner ramus almost as long as peduncle, with 2 robust setae on inner margin; outer ramus

222 length 0.7 times that of inner ramus, with outer marginal robust seta. Uropod 3 (Figure 5(f))

223 length 0.6 times that of uropod 1; both rami equal in length, length 1.2 times that of peduncle,

224 uniarticulate, each ramus with 2 subterminal setae; inner ramus with 5 and 2 robust setae on

225 inner and outer margins, respectively; outer ramus with 2 and 3 robust setae on inner and

226 outer margins, respectively. Telson (Figure 5(g)) tapering distally, length 1.3 times longer than

227 wide, cleft for 58\%, lateral margin not concave, with several sub-lateral and facial setae, each

228 lobe bearing 1 long and 1 short setae sub-apically, apex rounded. 


\section{Variation}

Antenna 1 of one paratype (KUZ Z2042) length 0.4 and 1.4 times that of body and antenna 2,

respectively.

\section{Distribution}

Known only from the type locality.

\section{DNA sequences}

238 In total, 3 sequences of the present paratype (KUZ Z1939) were determined by previous

239 studies (Tomikawa et al. 2014; Tomikawa et al. 2017; Nakano and Tomikawa 2018): nuclear

240 28S ribosomal RNA (AB778502; 787 bp), histone H3 (LC334142; 328 bp), mitochondrial

241 16S ribosomal RNA (LC334116; 418 bp), and cytochrome c oxidase subunit I (LC146870;

$242658 \mathrm{bp})$.

243

244 Etymology

245 The specific name is an adjective derived from the name of the type locality of this new

246 species. 
248

249

250

251

252

253

254

255

256

257

258

259

260

261

262

263

264

265

\section{Remarks}

Paramoera shakotanensis sp. nov. is characterized by the antennal sinus without sharp

incision and the small number of setae on maxillae 1 and 2 (up to three on the inner plate of the maxilla 1 and up to two on oblique inner row of the inner plate of the maxilla 2). The present species shares these features with $P$. austrina (Bate, 1862), P. (H.) crassicauda Staude, 1995, P. hermitensis_Barnard, 1932, and P. tristanensis Barnard, 1932. Paramoera shakotanensis sp. nov. can be distinguished from those five species by the following features (Bate 1862; Barnard 1932; Staude 1995): from P. austrina [features of P. austrina in parentheses], antennal sinus deep (shallow), epimeral plate 3 moderately (broadly) expanded posteriorly, and ventral margin of coxa of pereopod 4 rounded (almost straight); from $P$. crassicauda [features of $P$. crassicauda in parentheses], eyes large (small, reduced) and pereopod 7 with coxal gill (lacking); from $P$. hermitensis [features of $P$. hermitensis in parentheses], posterior margin of epimeral plate 3 smooth (posterior margin weakly serrate), telson length 1.3 (1.8) times longer than wide with almost straight (concave) lateral margins, and telson with sub-lateral and distal setae (distal setae only); and from P. tristanensis

[features of $P$. tristanensis in parentheses], posterior margin of epimeral plate 3 smooth (posterior margin slightly crenulate) and lateral margins of telson almost straight (convex) with (without) setae.

The original descriptions of $P$. fasciculate (Thomson, 1880), P. fissicauda (Dana, 1852), 
and P. litoralis (Oldevig, 1959) lack information of antennal sinus and setal numbers of

maxillae 1 and 2 (Dana 1852; Thomson 1880; Oldevig 1959). However, P. shakotanensis sp.

nov. is distinguished from $P$. fasciculate and $P$. litoralis by the following features: palm of propodus of gnathopods 1 and 2 with 4 and 5 robust setae, respectively on posteroproximal corners (2-3 and 3 robust setae, respectively in P. litoralis), telson tapering distally (lateral margins parallel in P. fasciculate) with sub-lateral setae (lacking lateral setae in P. litoralis). The insufficient description of $P$. fissicauda makes difficult to compare with the present new species. Bellan-Santini and Ledoyer (1974) described $P$. fissicauda based on materials from the Kerguelen and Crozet. Paramoera fissicauda described by them has the sharply incised antennal sinus and the maxillae 1 and 2 with many setae, and thus obviously differs from P. shakotanensis sp. nov. However, Bellan-Santini and Ledoyer's P. fissicauda has been considered to be an undescribed species (De Broyer and Jazdzewski 1993). Accordingly, the taxonomic relationship between $P$. shakotanensis sp. nov. and $P$. fissicauda remains subject to a future study.

Paramoera shakotanensis sp. nov. is also similar to P. anivae Labay, 2012 and $P$. erimoensis Kuribayashi and Kyono, 1995 in having an inferior antennal sinus lacking an incision, pereopod 7 with coxal gill, and rami of uropod 3 without plumose setae. However, $P$. shakotanensis can be distinguished from these two species by the following features (Kuribayashi and Kyono 1995; Labay 2012) [features of P. anivae and P. erimoensis in 
286

287

288

289

290

291

292

293

294

295

296

297

298

299

300

301

302

303

304

parentheses]: from $P$. anivae, peduncular article 2 gland cone of antenna 2 with 2 setae (with

6 setae), inner plate of maxilla 1 with 3 plumose setae (5 plumose setae), outer margin of palp article 2 of maxilla 1 without seta (with seta), inner plate of maxilla 2 with oblique inner row of 2 plumose setae (3 plumose setae); and from $P$. erimoensis, inner plate of maxilla 1 with 3 plumose setae (5 plumose setae), inner plate of maxilla 2 with oblique inner row of 2 plumose setae (3 plumose setae), and carpus of female gnathopod 2 longer than propodus (shorter than propodus).

Paramoera shakotanensis sp. nov. possesses large eyes despite this species inhabits interstitial habitats. Unlike the epigean species, the previously known hypogean Paramoera amphipods can be characterised by their eyes, which are vestigial or completely lacking, among other characteristics, and thus, four subgenera have been erected for those species (Staude 1995; Sidorov 2010). Of the four described subgenera, three subgenera, Moanamoera Staude, 1995, Humilomoera Staude, 1995 and Rhithromoera Staude, 1995, were erected by Staude (1995) for the subterranean and/or interstitial species distributed in the North Pacific. The subgenus Moanamoera was established for the Paramoera amphipod inhabiting brackish lava ponds in the Hawaiian Islands (Barnard 1977; Staude 1995), and the remaining two subgenera, i.e. Humilomoera and Rhithromoera, were erected from the interstitial subtidal and/or brackish pool species inhabiting the eastern coast of the North Pacific (Staude 1995). Recently, an additional subgenus, Ganigamoera Sidorov, 2010, was described for the 
(Sidorov 2010). The remaining species which were not included in those four subgenera have been assigned to the subgenus Paramoera (Staude 1995).

As described above, the new species bears morphological characteristics mostly consistent with the diagnosis of Humilomoera as defined by Staude (1995). However, the new species possesses large eyes and a coxal gill on pereopod 7, two characteristics that are at odds with Staude's (1995) definition of this subgenus. Eye reduction is a character that can differ even among two populations of the same species of amphipod if, for example, one population lives underground and the other inhabits surface waters (Culver et al. 1995). Therefore, the absence of eyes in the previously known Humilomoera species is deemed to be a highly derived character that is related to their interstitial habitats. Moreover, another subgenus, Rhithromoera, also contains species with and without a coxal gill on pereopod 7 (Staude 1995).

It was stated that the subgenus-level classification of Paramoera remained unresolved, when the two subgenera Humulomoera and Rhithromoera were erected (Staude 1995). Moreover, it was implied that the other subgenus Ganigamoera might not be a monophyletic taxon (Sidorov 2010). The subterranean P. relicta was once classified within the genus 
324 genetically close to the epigean P. koysama synonymizing Relictomoera with Paramoera.

325 Since the precise phylogenetic relationships among $P$. relicta and the other hypogean species classified within the three subgenera remained unresolved, Relictomoera was not treated as a valid subgenus in Nakano and Tomikawa (2018). Therefore, the new species from Hokkaido is not assigned to the subgenus Humilomoera as well as other subgenera, so as to avoid additional taxonomic confusion. To clarify the subgeneric assignment of $P$. shakotanensis sp. nov., as well as to test the validity of subgenus-level classification of Paramoera, a molecular phylogenetic study should be necessary along with evaluating morphological characteristics of all Paramoera species.

A few Paramoera species show sexual dimorphism in their pleopods (Kuribayashi and Kyono 1995; Sidorov 2010). The outer ramus of pleopod 2 in their males is modified as more or less shortened and broadened with thickened short setae distally, whereas that of the females shows usual form common in Paramoera (Kuribayashi and Kyono 1995; Sidorov 2010). However, it remains unclear whether P. shakotanensis sp. nov. exhibits sexual dimorphism in its pleopods, since any males of the new species have not been collected. The morphological characteristics of the males of P. shakotanensis sp. nov. should be documented by a future taxonomic study; the DNA sequences provided from the paratype of the new species will greatly help identify male individuals of the new species. 


\section{References}

Barnard JL. 1977. The cavernicolous fauna of Hawaiian lava tubes. 9. Amphipoda (Crustacea) from brackish lava ponds on Hawaii and Maui. Pac Insects. 17:267-299.

Barnard JL, Karaman GS. 1982. Classificatory revisions in gammaridean Amphipoda (Crustacea), part 2. Proc Biol Soc Wash. 95: 167-187.

Barnard KH. 1932. Amphipoda. Discovery Rep. 5: 1-326.

Bate CS. 1862. Catalogue of the Specimens of Amphipodous Crustacea in the Collection of the British Museum. London: British Museum.

Bellan- Santini D, Ledoyer M. 1974. Gammariens (Crustacea-Amphipoda) des Iles Kerguelen et Crozet. Tethys. 5:635-707.

Culver DC, Kane TC, Fong DW. 1995. Adaptation and natural selection in caves: the

Dana JD. 1852. Conspectus Crustaceorum quae in Orbis Terrarum circumnavigatione, Carolo

De Broyer C, Jazdzewski K 1993. Contribution to the marine biodiversity inventory. A 
intertidal zone of Hokkaido, northern Japan. Zool Sci. 7:955-959.

Jung TW, Kim JG, Yoon SM. 2016. Two new species of pontogeneiid amphipods (Crustacea, Senticaudata, Calliopioidea) from Korean waters. ZooKeys. 635:53-79.

Kuribayashi K, Kyono M. 1995. Two new species of the genus Paramoera (Amphipoda, transformed second pleopod. Crustaceana. 68:759-778.

Labay VS. 2012. Paramoera anivae a new species of Eusiridae Stebbing, 1888 (Crustacea: Amphipoda: Gammaridea) from the Okhotsk Sea. Zootaxa. 3475:69-85.

Miers EJ. 1875. Descriptions of new species of Crustacea collected at Kerguelen’s Island by the Rev. A. E. Eaton. Ann Mag Nat Hist Ser 4. 16:73-76. relicta synonymizes the genus Relictomoera with Paramoera (Crustacea: Amphipoda: Pontogeneiidae). Zool Sci. 35: 459-467.

Oldevig H. 1959. Arctic, Subarctic and Scandinavian Amphipods in the collections of the Swedish Natural History Museum in Stockholm. Goteborgs Kungl Vetenskaps- och Vitterhets-Samhalles Handlingar, sjatte foljden, ser B. 8:1-132 from subterranean waters and springs of the Eastern Sikhote-Alin Mountain Ridge, with comments on the morphology of sternal humps, genital papillae and pleopods. Zootaxa. 
Staude CP. 1995. The amphipod genus Paramoera Miers (Gammaridea: Eusiroidea:

Pontogeneiidae) in the eastern north Pacific. Amphipacifica. 1:61-102.

Stebbing TRR. 1906. Amphipoda I. Gammaridea. Berlin: R. Friedländer und Sohn. (Das

Tomikawa K, Kyono M, Kuribayashi K, Nakano T. 2017. The enigmatic groundwater amphipod Awacaris kawasawai revisited: synonymisation of the genus Sternomoera, with molecular phylogenetic analyses of Awacaris and Sternomoera species species of Sternomoera (Crustacea: Amphipoda: Pontogeneiidae) from Japan, with an analysis of the phylogenetic relationships among the Japanese species based on the 28S rRNA gene. Zool Sci. 31:475-490. 
Figure 1. Paramoera shakotanensis sp. nov., paratype, female, KUZ Z2042, lateral view.

Scale bar, $1.0 \mathrm{~mm}$.

401

Figure 2. Paramoera shakotanensis sp. nov., holotype, female, KUZ Z2041. (a) Head, lateral

Figure 3. Paramoera shakotanensis sp. nov., holotype, female, KUZ Z2041. (a) Maxilliped, anterior view. (b), (c) Inner and outer plates of maxilliped, anterior views. (d) Gnathopod 1,

Gnathopod 2, medial view. (g) Palmar margin of propodus and dactylus of gnathopod 2, 
416 Figure 4. Paramoera shakotanensis sp. nov., holotype, female, KUZ Z2041. (a-e) Pereopods 417 3-7, lateral (a), (c) and medial (b), (d), (e) views. Scale bars, $0.1 \mathrm{~mm}$.

419 Figure 5. Paramoera shakotanensis sp. nov., holotype, female, KUZ Z2041. (a-c) Pleopods

420 1-3, lateral (a), (c) and medial (b) views. (d-f) Uropods 1-3, ventral views. (g) Telson, ventral 421 view. Scale bars, $0.1 \mathrm{~mm}$. 